\title{
Severe bimaxillary protrusion with adult periodontitis treated by corticotomy and compression osteogenesis
}

\author{
Seong-Hun Kim, DMD, MSD, ${ }^{\text {a }}$ Kye-Bok Lee, DMD, ${ }^{b}$ Kyu-Rhim Chung, DMD, MSD, PhD, ${ }^{c}$ \\ Gerald Nelson, DDS, ${ }^{d}$ Tae-Woo Kim, DDS, MSD, $\mathrm{PhD}^{\mathrm{e}}$
}

\begin{abstract}
This paper describes the case of a 50-year-old female with a Class II malocclusion who presented with severe bimaxillary protrusion and generalized alveolar bone loss due to adult periodontitis. The treatment plan consisted of extracting both upper and lower first premolars and periodontal treatment. Anterior segmental osteotomy (ASO) of the mandible and upper anterior segment retraction using compression osteogenesis after peri-segmental corticotomy (Speedy orthodontics) was performed. Correct overbite and overjet, facial balance, and improvement of lip protrusion were obtained. However, a slight root resorption tendency was observed on the lower anterior dentition. The active treatment period was 9 months and the results were stable for 27 months after debonding. This new type of treatment mechanics can be an effective alternative to orthognathic surgery. (Korean J Orthod 2009;39(1):54-65)
\end{abstract}

Key words: Corticotomy, Speedy orthodontics, Skeletal anchorage, Compression osteogenesis, Anterior segment osteotomy, Adult periodontitis

${ }^{\text {aP }}$ ostgraduate student, Department of Orthodontics, School of Dentistry and Dental Research Institute, Seoul National University, and Assistant Professor, Department of Orthodontics, The Catholic University of Korea, Uijongbu St. Mary's Hospital.

${ }^{\mathrm{b}}$ Private Practice.

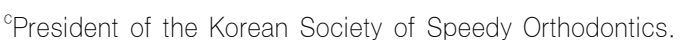

${ }^{\mathrm{d}}$ Clinical professor and Vice Chair, Department of Orthodontics, The University of California San Francisco.

${ }^{e}$ Professor and Chairman, Department of Orthodontics, School of Dentistry and Dental Research Institute, Seoul National University. Corresponding author: Tae-Woo Kim.

Department of Orthodontics, School of Dentistry and Dental Research Institute, Seoul National University, 28-2, Yeongeon-dong, Jongnogu, Seoul 110-744, Korea.

+82 22072 2671; e-mail, taewoo@snu.ac.kr.

Received October 8, 2008; Last Revision November 20, 2008; Accepted November 23, 2008.

DOl:10.4041/kjod.2009.39.1.54

"This study was partly supported by the Korean Society of Speedy Orthodontics, Alumni fund of the Department of Dentistry and Graduate School of Clinical Dental Science, The Catholic University of Korea.

\section{INTRODUCTION}

In adult patients with bimaxillary protrusion, correction may involve removal of four premolars. The anterior teeth may be retracted with fixed appliances, with or without orthognathic surgery. ${ }^{1-3}$

Currently, the number of middle-aged-patients with periodontal problems is increasing, as is the need for orthodontics. ${ }^{1,4}$ In adult patients with periodontal damage, orthodontic treatment requiring closure of extraction space has a high risk of side effects such as bone loss and root resorption.

Consequently, the clinician will minimize long-term treatment plans and avoid unnecessary or difficult tooth movements in order to reduce the risk. ${ }^{5}$ One way to achieve this goal is the use of a segmental osteotomy. ${ }^{6-8}$ This procedure will remove some of the limits to tooth movement and shorten the time period required. The downside is concern about side effects such as loss of tooth vitality, avascular necrosis in the 
bone segment, and the typical risks of general anesthesia and hospitalization. Proximity of roots must be carefully evaluated during the surgery and retraction procedures.

Köle ${ }^{9}$ introduced a corticotomy technique to enable the movement of a bone segment that includes a tooth by sectioning of the layer of compact bone. It is a surgical technique which allows the fairly rapid movement of a tooth or group of teeth without requiring the teeth to move a great distance through bone. A corticotomy poses less risk than a segmental osteotomy or orthognathic surgery. ${ }^{10-15}$ Risks during corticotomy procedures are increased if there is active periodontal inflammation or disease or if excess heat is released during the procedure.

\section{Speedy orthodontics}

"Speedy Orthodontics" describes a protocol to allow movement of dental segments over a reduced time period using a coricotomy and the application of an orthopedic force using intraosseous anchorage. ${ }^{16-18}$ The force applied after the corticotomy is heavier than the typical orthodontic force, since the goal is to move the block of bone that has been circumscribed by compression osteogenesis rather than moving teeth through the bone. 19,20 "Compression osteogenesis" first named by Chung is described as histologic changes through orthopedic traction forces to a corticotomized segment. The medullar bone around the anterior teeth can be easily bent by the retraction force if the cortical layer

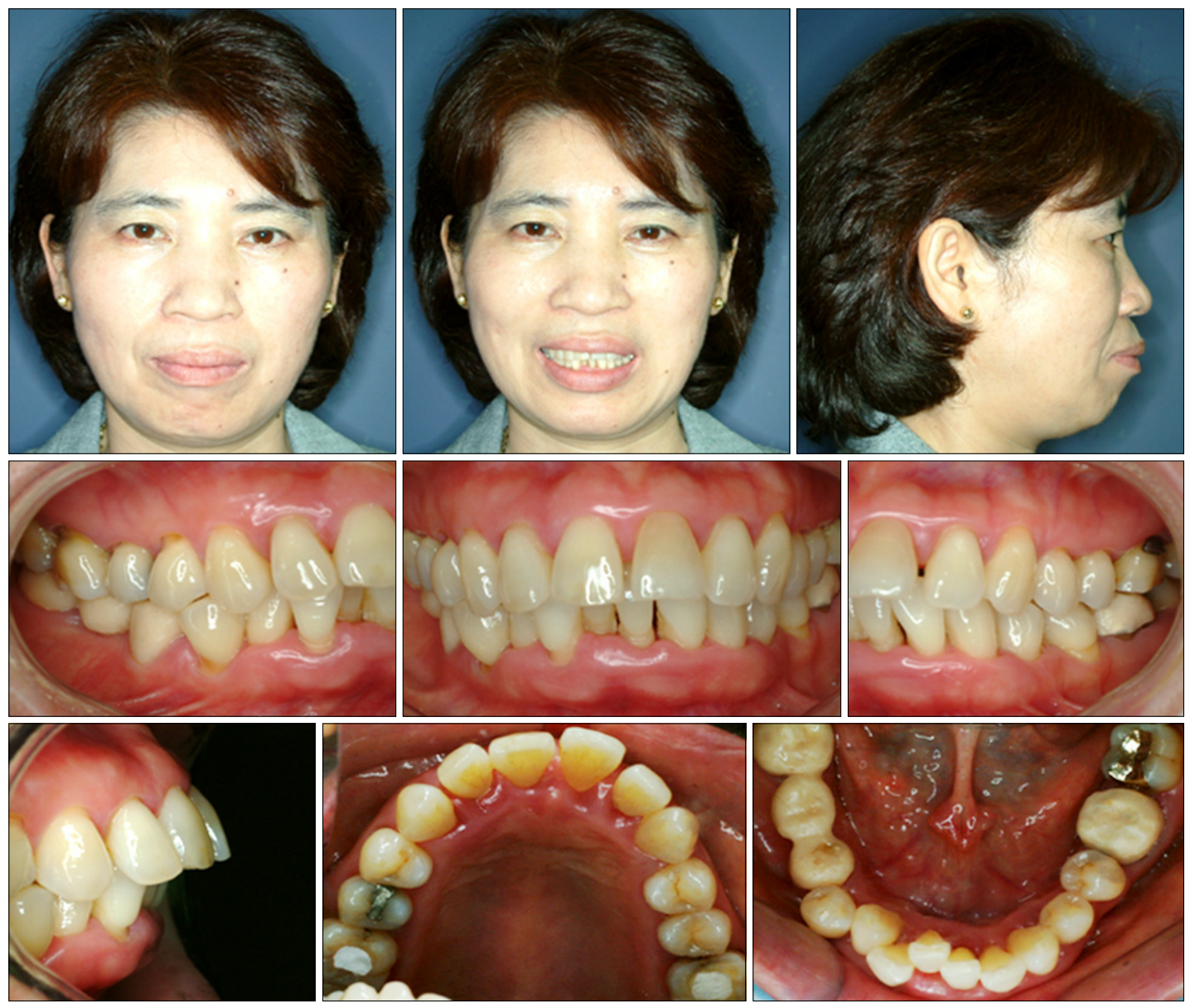

Fig 1. Facial and intraoral photographs before treatment show a very convex profile with significant mentalis muscle strain and reveal a Class II canine and Class I molar relationship. 
between the basal and alveolar bones is removed. ${ }^{16,17}$ The following case report for an adult female patient portrays the technique we call "Speedy orthodontics". The treatment was preceded by periodontal care until the active disease was under control. There was significant facial improvement without any deterioration of her periodontal status.

\section{DIAGNOSIS AND ETIOLOGY}

This female patient, aged 50 years, 10 months, presented with pronounced dental and labial protrusion, and advanced periodontal disease. Pocket depths ranged from 4 - $8 \mathrm{~mm}$. All molar furcations were affected, and the mandibular incisors were over-erupted. She was treated with universal curettage and periodontal surgery, and followed until basic periodontal health was evident.

The extraoral examination revealed a very convex profile with significant mentalis muscle strain. The in- traoral examination revealed a Class II canine and Class I molar relationship. In the maxilla, the anteriors were spaced and severely protruded. The mandibular anteriors were moderately crowded (Figs 1 and 2). Lateral cephalometric view revealed that the patient had a skeletal Class II relationship (ANB angle $=3.2^{\circ}$, Mx.1 to NA angle $=30.7^{\circ}$, Mx.1 to NA distance $=$ $11.5 \mathrm{~mm})$, a steep occlusal plane $(\mathrm{SN}-\mathrm{OP}$ angle $=$ $\left.20.6^{\circ}\right)$, a high mandibular plane angle $\left(\mathrm{FMA}=32.2^{\circ}\right.$ ), and proclined incisors (Interincisal angle $=114.4^{\circ}$, Mandibular incisor to $\mathrm{NB}$ angle $=31.7^{\circ}$, Mandibular incisor to NB distance $=12.3 \mathrm{~mm}$ ) (Fig $3 A$, Table 1). The diagnosis was a skeletal Class II malocclusion with bidentoalveolar protrusion and compromised periodontal status. The panoramic radiogram revealed a missing lower right first molar. The periodontal bone levels were low as shown as Fig $3 B$.
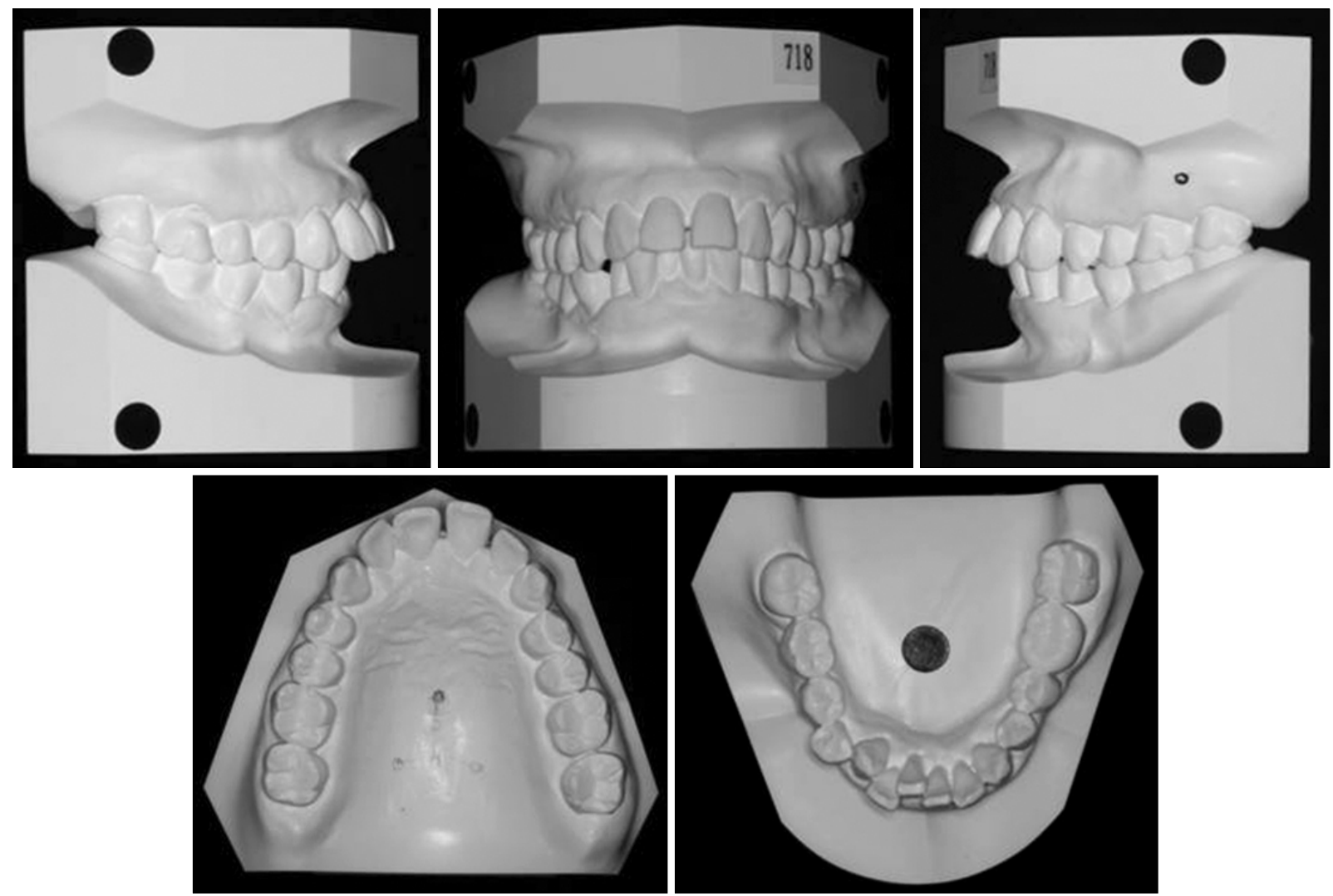

Fig 2. Pretreatment study models. 

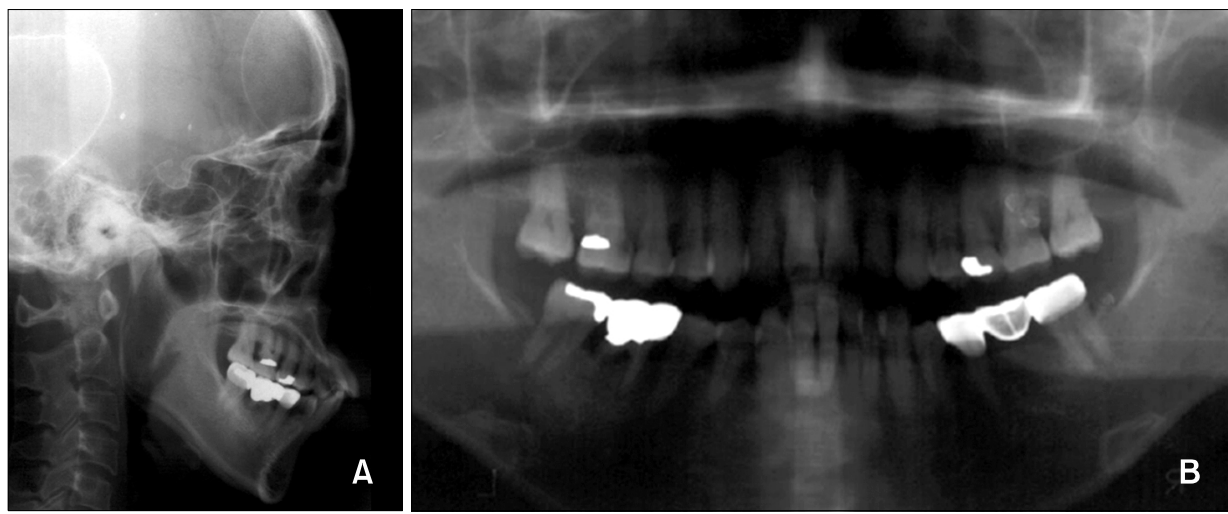

Fig 3. Radiographs before treatment. A, Cephalogram; B, panoramic radiograph.

Table 1. Cephalometric measurements pre- and posttreatment

\begin{tabular}{lccc}
\hline & $\begin{array}{c}\text { Average } \\
(\text { Female })\end{array}$ & $\begin{array}{c}\text { Pre }^{-} \\
\text {treatment }\end{array}$ & $\begin{array}{c}\text { Post- } \\
\text { treatment }\end{array}$ \\
\hline \hline SNA $\left(^{\circ}\right)$ & 81.6 & 82.5 & 81.4 \\
SNB $\left(^{\circ}\right)$ & 79.2 & 79.3 & 76.1 \\
ANB $\left(^{\circ}\right)$ & 2.4 & 3.2 & 5.3 \\
& $85.1 / 127.4$ & $85.2 / 134.3$ & $85.5 / 135.5$ \\
PFH/AFH $(\%)$ & $(66.8 \%)$ & $(63.4 \%)$ & $(63.1 \%)$ \\
SN-OP $\left(^{\circ}\right)$ & 17.9 & 18.7 & 19.0 \\
FH-UI $\left(^{\circ}\right)$ & 116.0 & 121.0 & 98.6 \\
FMA $\left(^{\circ}\right)$ & 24.3 & 32.2 & 32.5 \\
IMPA $\left(^{\circ}\right)$ & 95.9 & 93.7 & 96.4 \\
FMIA $\left(^{\circ}\right)$ & 59.8 & 54.1 & 51.1 \\
UL-E plane $(m m)$ & -0.9 & 5.7 & 2.5 \\
LL-E plane $(m m)$ & 0.6 & 8.2 & 0.9 \\
Interincisal angle $\left({ }^{\circ}\right)$ & 123.8 & 114.4 & 132.4 \\
Mx 1 To NA $(m m)$ & 7.3 & 11.5 & 7.0 \\
Mx 1 To NA $\left({ }^{\circ}\right)$ & 25.3 & 30.7 & 15.7 \\
Mn 1 To NB $(m m)$ & 7.9 & 12.3 & 11.2 \\
Mn 1 To NB $\left({ }^{\circ}\right)$ & 28.4 & 31.7 & 27.7 \\
SN To PP $\left({ }^{\circ}\right)$ & 10.2 & 5.2 & 3.4 \\
\hline
\end{tabular}

\section{TREATMENT OBJECTIVES}

The treatment objectives based on the analysis of the cephalometric tracings, dental $\mathrm{x}$-rays, photographs, and study models were to extract all the first premolars, align and retract the anterior teeth, improve the interincisal angle relationship, decrease the lip protrusion, maintain the posterior occlusal relationship, and improve the convex profile - all without a deterio- ration of the periodontal condition.

\section{TREATMENT ALTERNATIVES}

After the diagnosis, three treatment options were considered:

Fixed appliances with removal of two maxillary premolars and two mandibular incisors, retracting the maxillary anterior teeth against mini-screw anchors.

Remove the upper and lower first premolars, then perform a corticotomy to outline a block of bone around the maxillary anteriors and retract the mandibular anteriors with an anterior segmental osteotomy under local anesthesia. Use the C-lingual retractor and C-plate in the maxilla as rigid anchorage. ${ }^{21-24}$

Remove the four first premolars and perform anterior segmental osteotomies in both arches to affect the retraction surgically under general anesthesia.

The patient chose the second option even though she was made aware that the lower anterior teeth were more periodontally at risk than the lower first premolars. She noted the advantages of a shortened treatment time and felt the overall risks were less. The schematic illustration of Speedy Orthodontics treatment is shown in Fig 4. In the selected treatment option, maxillary fixed orthodontic appliances would be used to align the anteriors, stabilize during en masse retraction, and to detail the finish. In the mandible, brackets would be placed after surgical stabilization for about 6 weeks. She was advised that the lower anterior alignment would not be stable on its own and that, in 


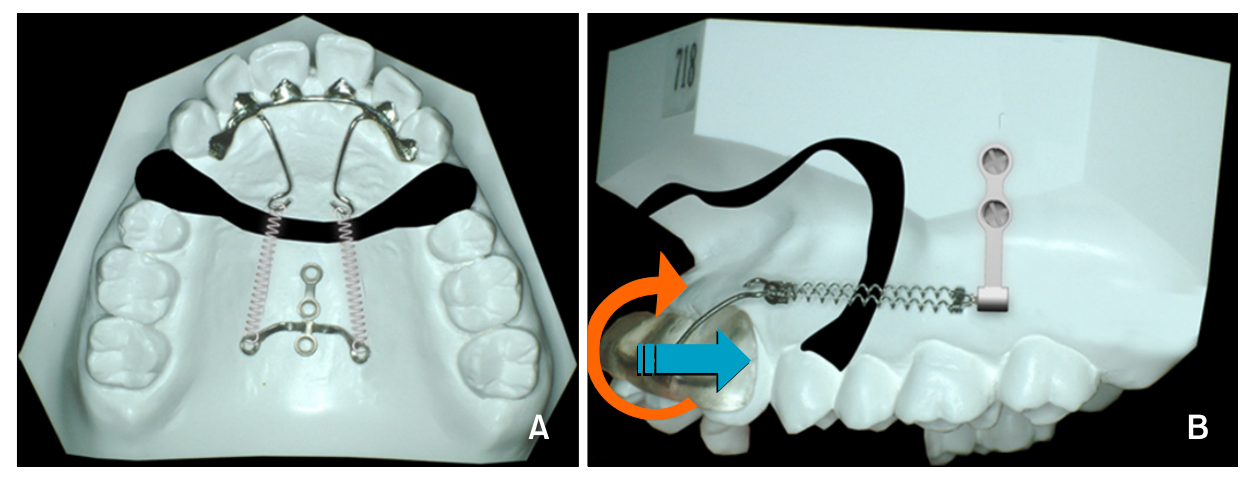

Fig 4. Schematic illustration of the anterior segment retraction method after perisegmental corticotomy. A, Titanium C palatal plate, drill free screws and $\mathrm{C}$ lingual retractor combined lingual retraction; $\mathbf{B}$, labial retractor and $\mathrm{C}$ tube combined retraction mechanics.
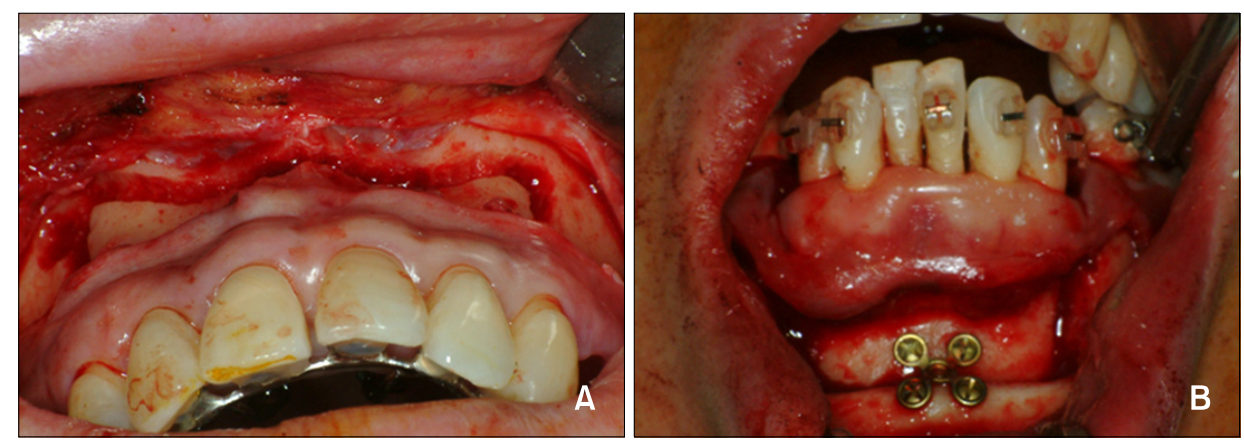

Fig 5. Oral view during speedy orthodontics surgery. A, Oral view after buccal perisegmental corticotomy; B, anterior segmental osteotomy (ASO) on the lower anterior segment.

any case, the periodontal prognosis for the lower anteriors was quite guarded.

\section{TREATMENT PROGRESS}

After a three month stabilization of the periodontal status, and home care was improved, the designated teeth were removed and corticotomy was performed in the maxilla, and anterior segmental osteotomy performed in the mandible under local anesthesia (Fig 5). In the maxilla, a mucoperiosteal incision was made along the palatal mucosa and the bone was exposed sparing the incisal nerve and artery. A vertical and horizontal bone cut was made across both the first premolar sites with the \# 5 round bur in a contra-angle handpiece. Two weeks later, to allow reconnection of the palatal blood supply after the palatal corticotomy, a buccal corticotomy was executed and a C-plate, a
$\mathrm{C}$-lingual retractor and a $\mathrm{C}$-tube were installed (Figs $5 A$ and 6). Fixed orthodontic appliances were placed on the maxillary posterior teeth and lower teeth, followed by the mandibular anterior segmental osteotomy, which was fixed with plates and screws, and further stabilized with a $0.017^{\prime \prime} \times 0.025^{\prime \prime}$ stainless steel archwire. In the maxilla, the anterior teeth were fixed into a single unit with the lingual retractor and a labial bonded wire. The retraction force of 500 - 900 gm per side was applied to both labial and lingual fixtures (Figs 7 and 8). In the mandible, after a healing period of about 6 weeks, leveling and alignment began. In the maxilla, retraction of the anterior corticotomized segment required five months, after which the $\mathrm{C}$-lingual retractor was removed and anterior brackets placed for four more months to level and align the anterior teeth. All maxillary appliances were debonded after nine months of active treatment. Fixed and removable re- 

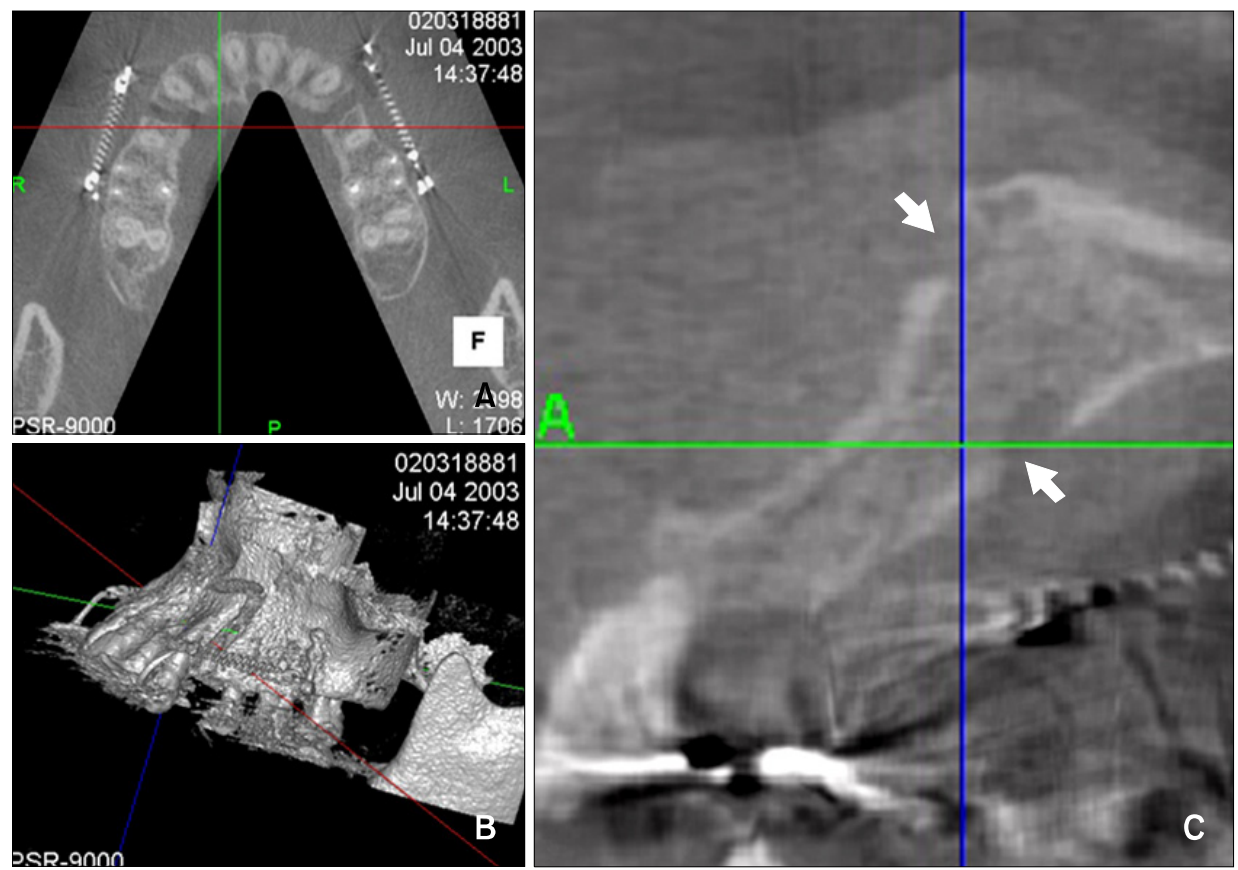

Fig 6. Cone beam CT view (PSR-9000N, Asahi Roentgen, Kyoto, Japan) after perisegmental corticomy. A, Transaxial view; B, 3 dimensional reconstruction view shows the labial perisegmental corticotomized area; C, arrows in sagittal view show depth of corticotomy.
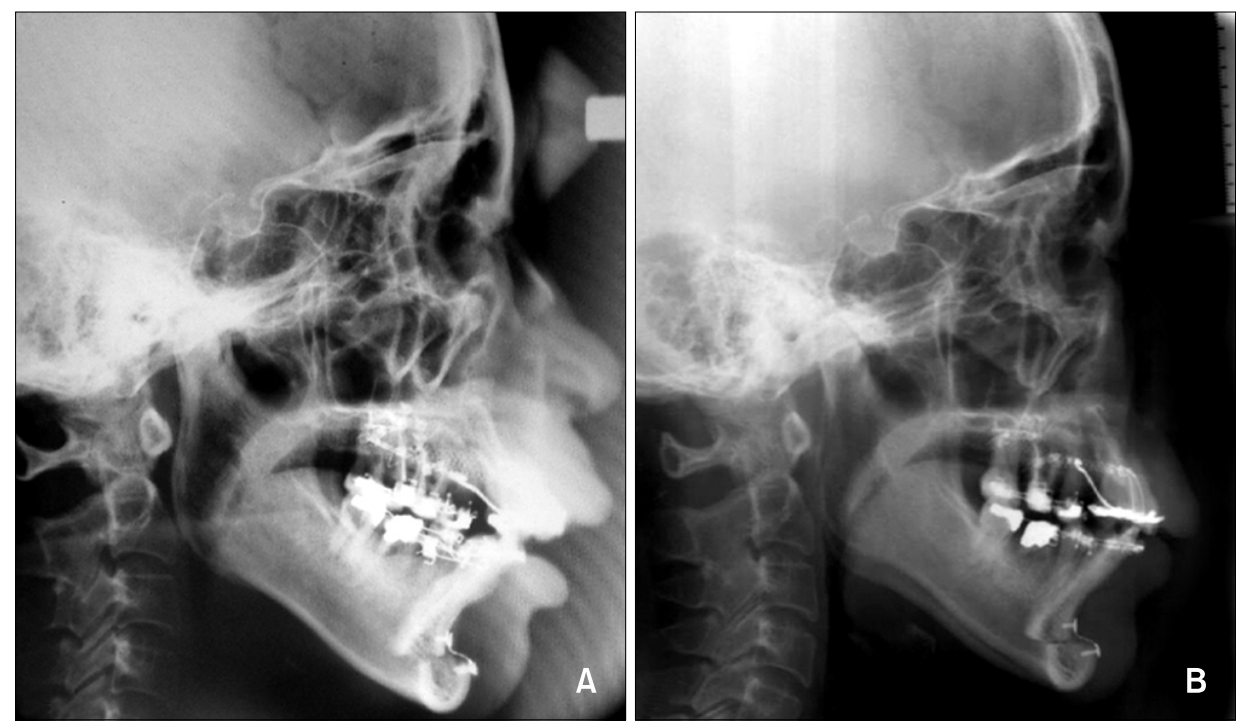

Fig 7. Progress on lateral cephalograms. A, 1 week after immediate upper retraction; B, 7 weeks after retraction.

tainers were prescribed due both to the periodontal status and potential for elastic rebound in the surgical sites.

\section{RESULTS}

After nine months of treatment, proper occlusion and alignment was obtained. Good overjet, overbite, facial 

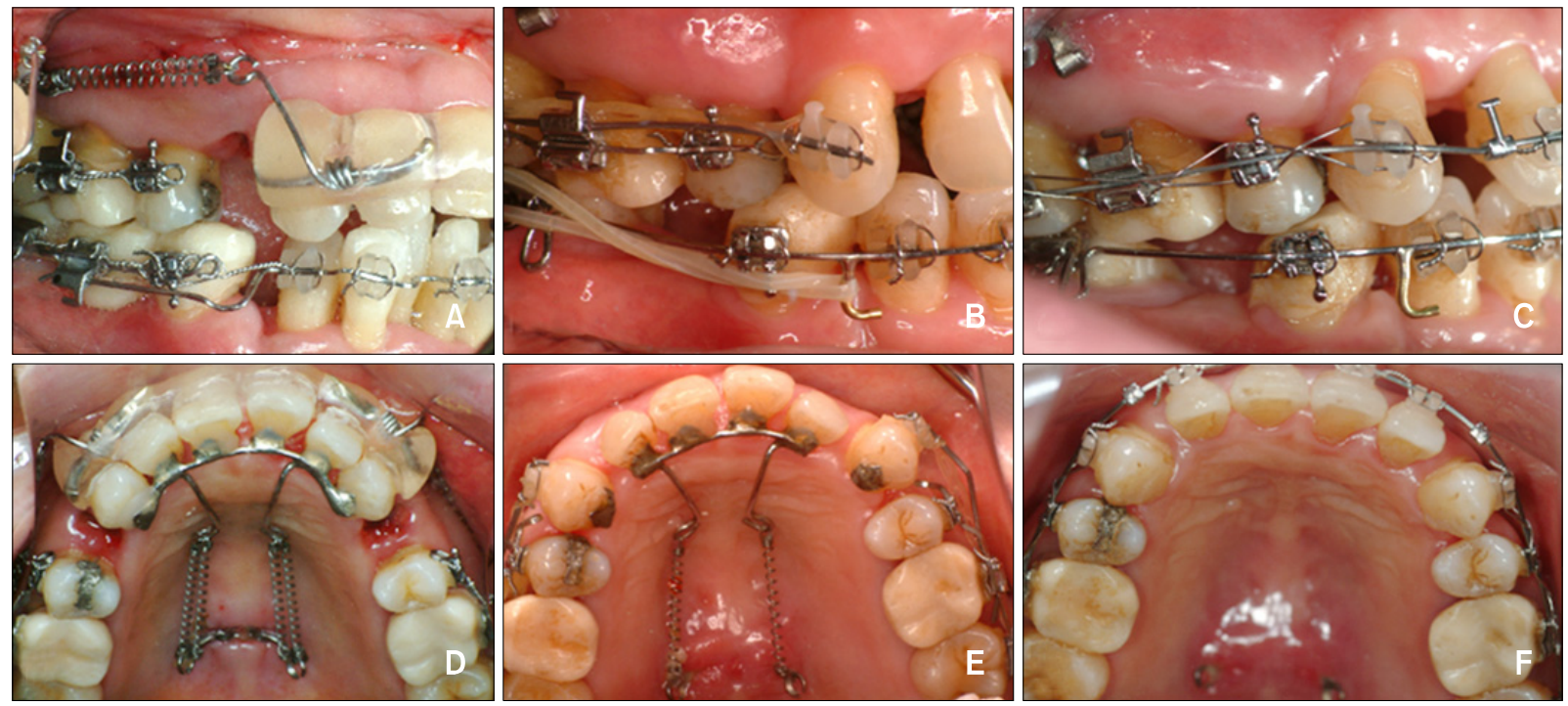

Fig 8. Progress in oral views. A and D, 1 week after retraction; B and E, 5 months after retraction; C and F, 6 months after treatment. Fixed appliances were applied for conventional orthodontic treatment.
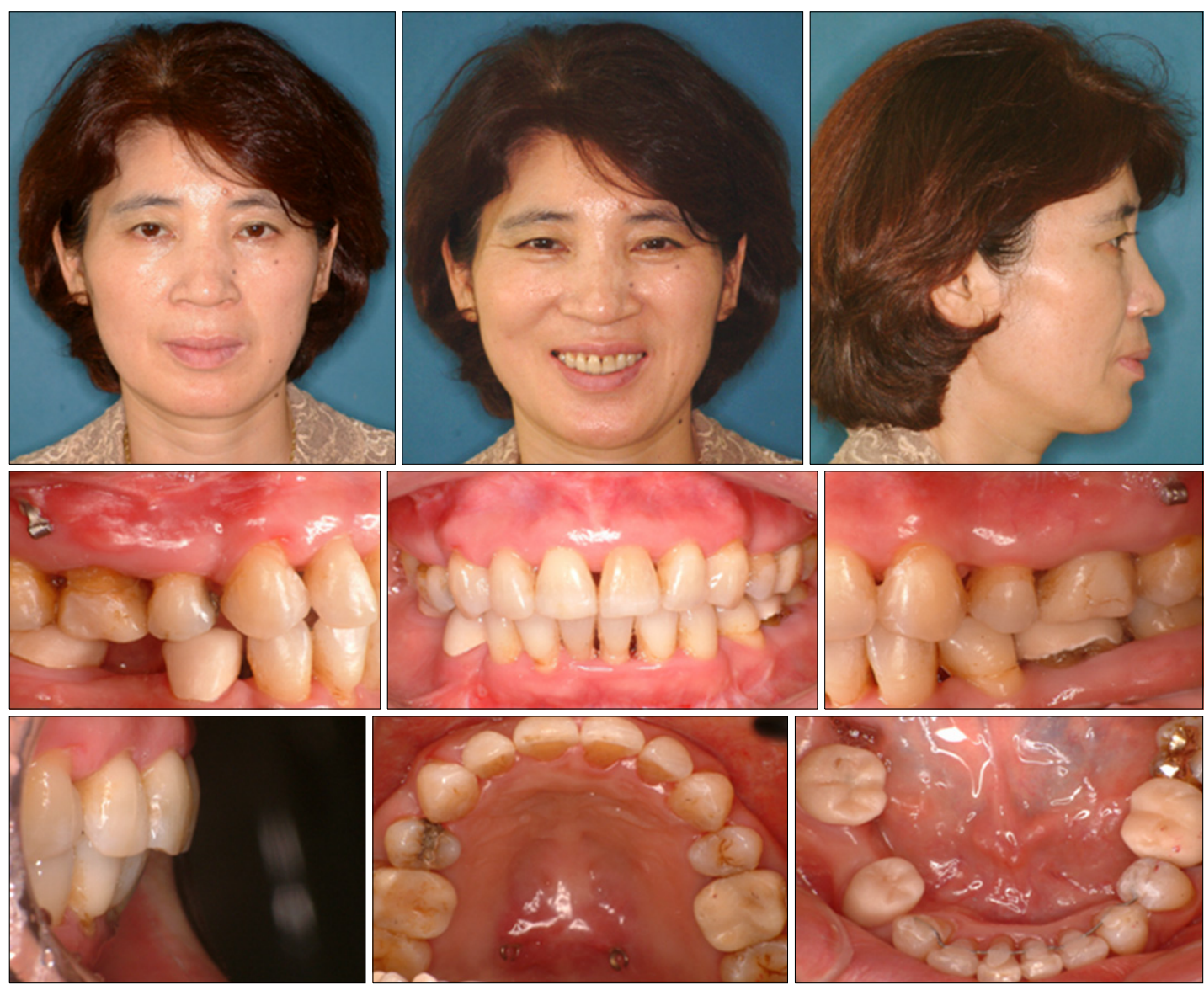

Fig 9. Facial and intraoral photographs after treatment show good overjet, overbite, facial balance, and a reduction of hypermentalis activity. 


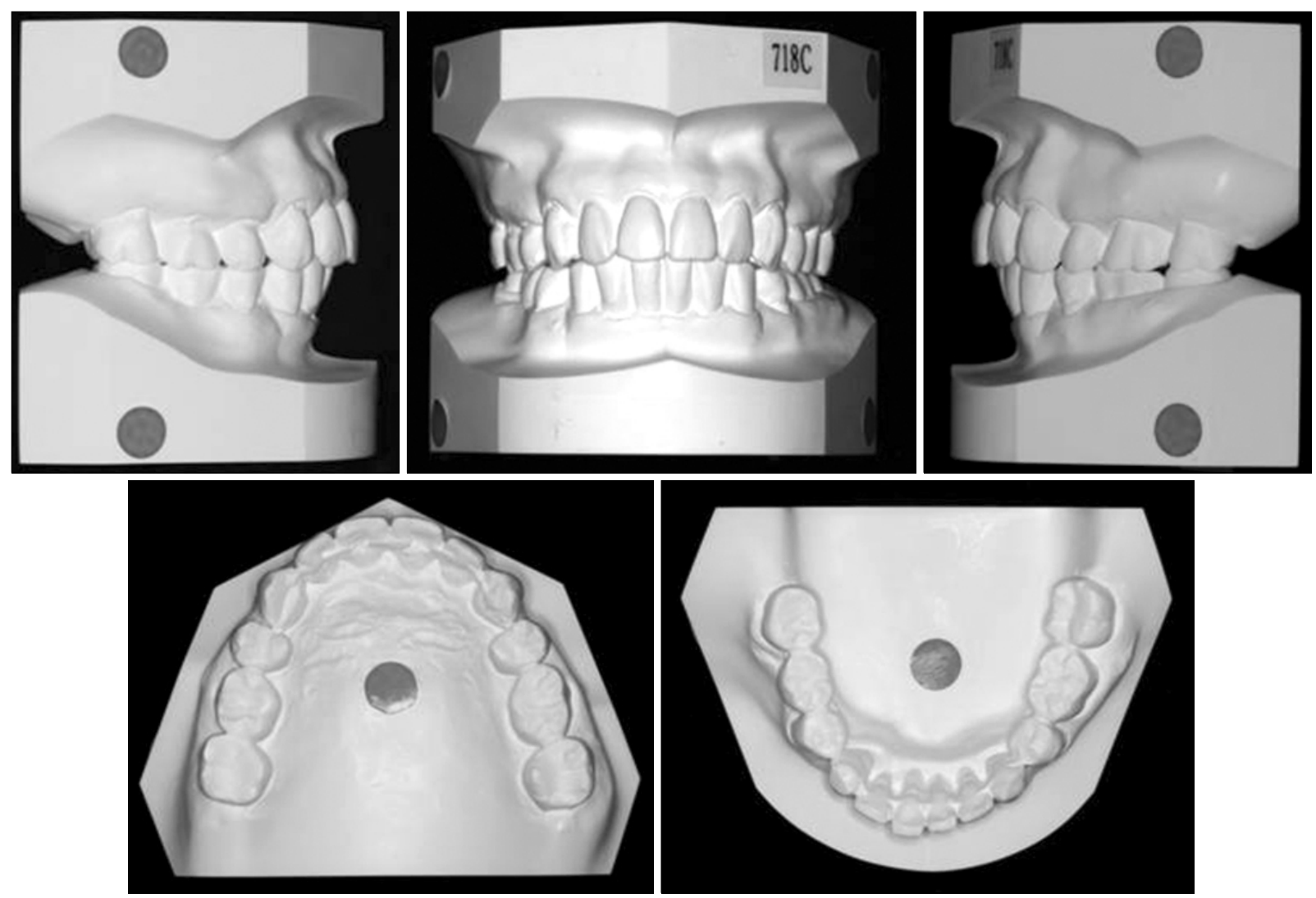

Fig 10. Post-treatment study models.
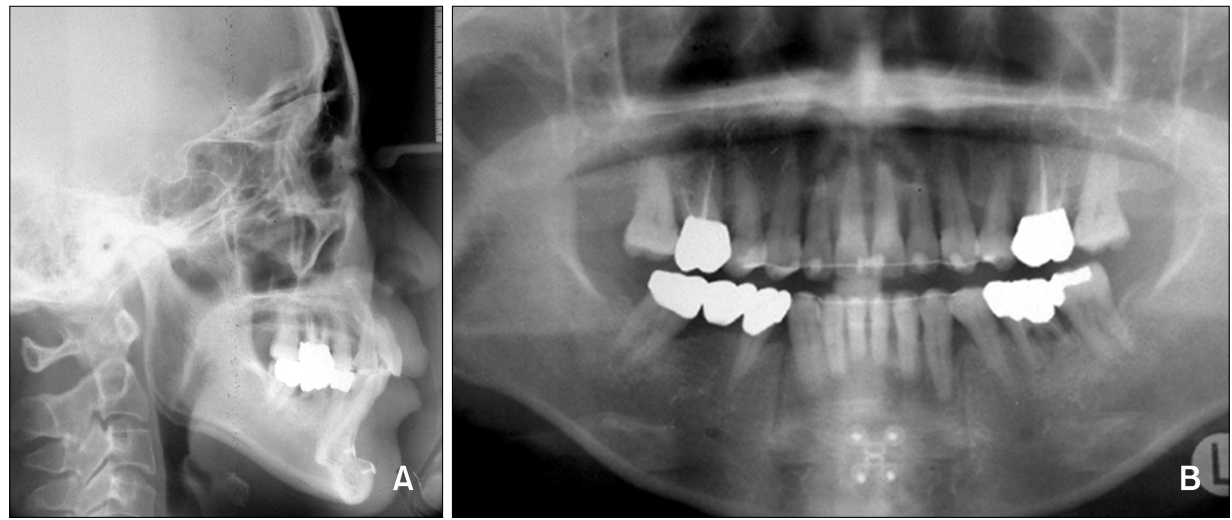

Fig 11. Radiographs after treatment. A, Cephalogram; B, panoramic radiograph.

balance, and a reduction of hypermentalis activity were also achieved and the pretreatment Class I molar relationship was maintained. A slight Class II canine relationship was obtained but with the midlines coincident (Figs 9 and 10). Cephalometric analysis showed a slight increase of FMA $\left(32.2^{\circ} \rightarrow 32.5^{\circ}\right)$, and the occlusal plane (SN to OP angle; $15.1^{\circ} \rightarrow 19.3^{\circ}$ ) (Figs 11 and 12). The upper incisors were significantly 
retracted through the rigid anchorage provided by the C-lingual retractor and C-plate (FH-U1 angle $121^{\circ} \rightarrow$ $98.6^{\circ}$, Maxillary incisor to NA distance $11.5 \mathrm{~mm} \rightarrow 7$ $\mathrm{mm}$, Maxillary incisor to NA angle $30.7^{\circ} \rightarrow 15.7^{\circ}$ ). The ANB increased a little during treatment from $3.2^{\circ}$ to $5.3^{\circ}$. The lower incisors were flared out a little because of application of intrusive mechanics and alignment of the severe crowding (IMPA 93. $7^{\circ} \rightarrow$ $96.4^{\circ}$, FMIA $54.1^{\circ} \rightarrow 51^{\circ}$, Mandibular incisor to NB distance $12.3 \mathrm{~mm} \rightarrow 11.2 \mathrm{~mm}$, Mandibular incisor to NB angle $31.7^{\circ} \rightarrow 27.7^{\circ}$ ). Marked retraction of lip

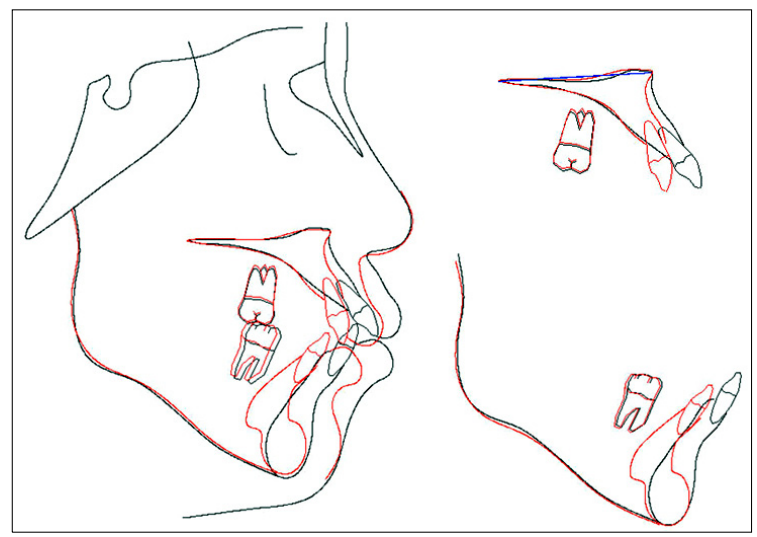

Fig 12. Superimpositions of lateral cephalograms: pretreatment (black line) to post-treatment (red line). posture was noted, especially of the lower lip (Upper Lip to E-plane $5.7 \mathrm{~mm} \rightarrow 2.5 \mathrm{~mm}$, Lower Lip to E-plane $8.2 \mathrm{~mm} \rightarrow 0.9 \mathrm{~mm})$. The interincisal angle increased significantly $\left(114.4^{\circ} \rightarrow 132.4^{\circ}\right)$ due to anterior bone segment bending. The posterior/anterior facial height ratio decreased a little after treatment $(63.4 \% \rightarrow 63.1 \%)$. There was no change in the periodontal status from before to after treatment. Alignment and intrusion of the lower incisors was associated with mild root-end resorption (Fig 11B). The patient was pleased with the final treatment result. The treatment results were still maintained after 27 months (Fig 13).

\section{DISCUSSION}

An adult patient, aged 50 years and 10 months with a poor periodontal condition and severe bimaxillary protrusion was considered unsuitable for typical orthodontic treatment with extractions and full fixed appliances due to the high risk of periodontal deterioration and root-end resorption. The patient held an urgent esthetic goal to retract the lips and teeth. After considering the options, the patient agreed to maxillary perisegmental corticotomy and lower ASO with maxillary fixed anchorage, a treatment protocol developed as an
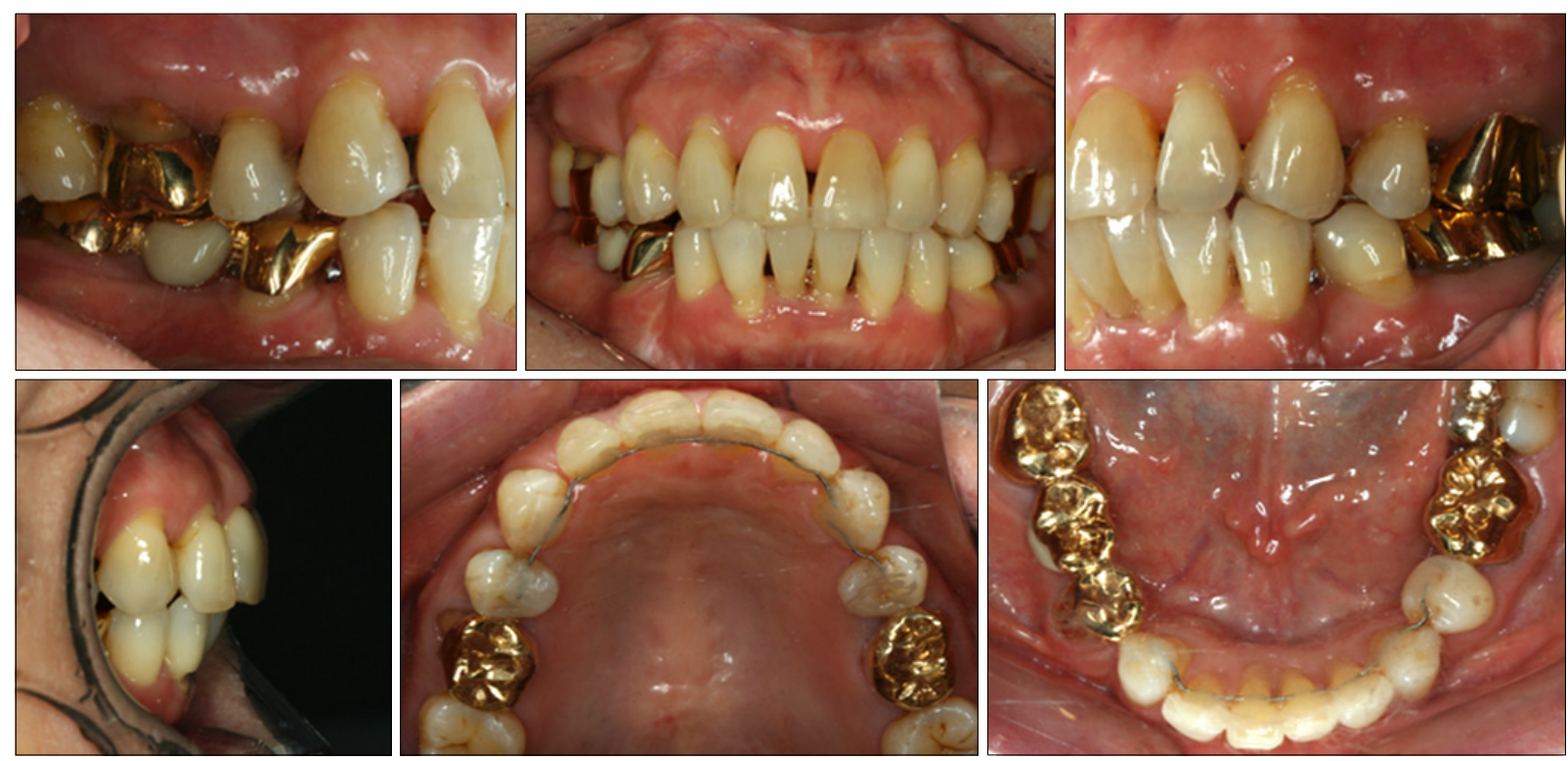

Fig 13. 27-month postretention intraoral photographs. 
efficient ambulatory surgical approach, and called "Speedy Orthodontics". This protocol takes advantage of the concept of compression osteogenesis ( $\mathrm{CO}$ ) in the corticotomized segment during orthopedic traction and is usually performed under local anesthesia. ${ }^{16,17,20} \mathrm{CO}$ is performed by compressing two cut bone surfaces together after corticotomy. According to Kawakami et al's animal study, after coroticotomy, there was an increase in the number of cells, the irregularity of functional arrangement of cells and fibers, the amount of bone resorption and apposition, and the width of sutures. ${ }^{25}$ Changes were seen mostly in the cortical layer, while minimal changes were noticeable in spongeous bone. The medullary bone around anterior teeth can be easily bent by heavy retraction force if the cortical layer between the basal and alveolar bones is interrupted. Speedy Orthodontics is different from the accelerated osteogenic orthodontics (AOO) developed by Wilcko in that it requires removal of a track of cortical bone rather than punctures in the cortical plate, followed by orthopedic traction against the isolated block of bone and teeth. ${ }^{16-20}$

If periodontal disease is present, it must be treated and stabilized, and proper home care established prior to any orthodontic treatment, and this is especially important for a patient for whom Speedy Orthodontics is planned. This was made clear in an animal experiment by Ericsson et al. ${ }^{26}$ The orthodontic movement of plaque-infected teeth can alter the formation of the connective tissue attachment and induce an infrabony pocket. He noted that the plaque moved from the supragingival area subgingivally during tipping and intrusion movements. For an adult patient with a history of periodontal disease and bone loss, it is wise to avoid tipping movements. Bodily translation is healthier if force on the periodontium is lessened. ${ }^{27}$ The maxillary palatal and buccal corticotomies were done at different times, two weeks apart. ${ }^{16,17}$ This minimizes the obstruction of blood circulation and lessens the burden to both operator and patient.

This patient had severe periodontal involvement in both arches, and especially of the mandibular anterior teeth. There are many controversial considerations in treating such an orthodontic patient with severe periodontal disease. We discussed the treatment options of removal of the two mandibular central incisors, upper and lower ASO, or limited orthodontic approaches. We were aware of the guarded periodontal prognosis of the mandibular incisors, compared with the patient's extracted two mandibular premolars, which were periodontally healthier than the mandibular incisors. The two-year posttreatment records show that further bone loss had occurred around the mandibular incisors. Perhaps a more prudent plan would have been to remove the two compromised incisors rather than the mandibular premolars. However, segmental retraction as we performed seemed to have the advantage of very minimal orthodontic intervention in the lower arch, and allowed us to maintain a reasonable lower incisor proclination angle. The chosen treatment also allowed immediate intrusion of the lower anterior segment, which facilitated the maxillary retraction. The objective was about a four $\mathrm{mm}$ setback and three $\mathrm{mm}$ intrusion.

In the maxilla, the level of orthopedic force was taken from Suya, ${ }^{19}$ Kawakami et $\mathrm{al}^{25}$ and Yoshikawa ${ }^{28}$, theory, a force of 500 to 900 grams per side was applied to the C-plate and C-tube. Fukanaga et al have tried to retract the anterior dentition in patients exhibiting bone loss using skeletal anchorage. ${ }^{29}$ The result was disappointing due to excess tipping and the relapse tendency. In this case, we avoided these effects by uniting the anterior teeth into a unit by bending back the premaxillary segment, taking advantage of $\mathrm{CO}$ to reduce the insult on the roots of the teeth both in pressure and time. No root-end resorption of the maxillary incisors was evident. A post active treatment panorama showed some tendency of root-end resorption of the lower incisors. This would likely have been worse with orthodontic movement alone. Readers can note that we applied force to the maxillary segment both on the lingual to the C-lingual retractor, and on the labial to the $\mathrm{C}$-tube. The purpose was to provide bodily retraction rather than simply tipping the segment back. We estimated the center of resistance to be more apical in a case with reduced bone support. ${ }^{30}$

\section{CONCLUSION}

As shown in this reported case of an adult with severe periodontal disease and bimaxillary protrusion, 
careful treatment of periodontal disease and appropriate periodontal maintenance during treatment allowed a protocol of treatment using perisegmental corticotomy and skeletal anchorage under local anesthesia to provide a correction that could be used as an alternative to orthognathic surgery.

- 국문초록 -

치조골 소실과 심한 양악전돌을 동반한 성인환자에서의 피질골 절단술과 compression osteogenesis를 이용한 교정치료

$$
\text { 김성훈 }^{\mathrm{a}} \cdot \text { 이계복 }{ }^{\mathrm{b}} \cdot \text { 정규림 }^{\mathrm{c}} \cdot \text { Gerald Nelson }^{\mathrm{d}} \cdot \text { 김태우 }^{\mathrm{e}}
$$

본 증례보고는 성인형 치주염으로 인해 전반적인 치조골 소실을 보이고 양악 전돌을 동반한 I급 부정교합으로 진단 된 50 세 10 개월 된 여자환자의 치료를 소개하고자 한다. 치 주 치료를 진행한 후 양악 전돌을 해소하기 위해 양악 제1소 구치를 발치하고, 상악 전치부는 피질골 절단술 시행 후 악 정형적 견인을, 하악 전치부는 6 전치의 전방부 분절골 절단 술[Anterior segment osteotomy (ASO)]을 국소마취하에 시 행하였다. 총 치료기간은 9 개월이 소요되었고 안정적인 교합 관계와 안모의 개선이 이루어졌다. 하지만 치료 후에 하악 전치부에 약간의 치근 흡수 소견이 관찰되었다. 치료 27 개월 후에도 안정적인 치료결과가 유지되었다.

주요 단어: 피질골 절단술, 급속수술표정, 골격성 그정원, Compression osteogenesis, 전방부 분절 골 절단술, 성인형 치주염

\section{REFERENCES}

1. Melsen B. Limitations in adult orthodontics. In: Melsen B editor. Current controversies in orthodontics. Chicago: Quintessence Publishing; 1991.

2. Handelman CS. The anterior alveolus: its importance in limiting orthodontic treatment and its influence on the occurrence of iatrogenic sequelae. Angle Orthod 1996;66:95-109.

3. Proffit WR, White RP Jr. Who needs surgical-orthodontic treatment? Int J Adult Orthodon Orthognath Surg 1990;5:81-9.

4. Miyajima K, Nagahara K, Lizuka T. Orthodontic treatment for a patient after menopause. Angle Orthod 1996;66:173-8.

5. Newman WG. Possible etiologic factors in external root resorption. Am J Orthod 1975;67:522-39.

6. Bell WH, Jacobs JD, Legan HL. Treatment of Class II deep bite by orthodontic and surgical means. Am J Orthod 1984; $85: 1-20$

7. Bojrab DG, Dumas JE, Lahrman DE. JCO/interviews Dr.
David G. Bojrab, Dr. James E. Dumas, Dr. Don E. Lahrman on surgical-orthodontics. J Clin Orthod 1977;11:330-42.

8. Laigan DT, Hey JH, West HA. Aseptic necrosis following maxillary osteotomies: report of 36 cases. J Oral Maxillofac Surg 1990;48:142-56.

9. Köle H. Surgical operations on the alveolar ridge to correct occlusal abnormalities. Oral Surg Oral Med Oral Pathol 1959; 12:515-29.

10. Bell WH. Surgical-orthodontic treatment of interincisal diastemas. Am J Orthod 1970;57:158-63.

11. Anholm JM, Crites DA, Hoff R, Rathbun WE. Corticotomy-faciliated orthodontics. CDA J 1986;14:7-11.

12. Düker J. Experimental animal research into segmental alveolar movement after corticotomy. J Maxillofac Surg 1975;3:81-4.

13. Gantes B, Rathbun E, Anholm M. Effects on the periodontium following corticotomy-facilitated orthodontics. Case reports. J Periodontol 1990;61:234-8.

14. Park WK, Kim SS, Park SB, Son WS, Kim YD, Jun ES, et al. The effect of cortical punching on the expression of OPG, RANK, and RANKL in the periodontal tissue during tooth movement in rats. Korean J Orthod 2008;38:159-74.

15. Wilcko WM, Wilcko T, Bouquot JE, Ferguson DJ. Rapid orthodontics with alveolar reshaping: two cases reports of decrowding. Int J Periodontics Restorative Dent 2001;21:9-19.

16. Chung KR. Text book of speedy orthodontics. Seoul: Jeesung; 2001.

17. Chung KR, Kim SH, Kook YA. Speedy surgical orthodontic treatment with skeletal anchorage in adults. In: Bell WH, Guerrero CA editors. Distraction osteogenesis of the facial bones. Hamilton: BC Deckers; 2007. p. 167-86.

18. Chung KR, Oh MY, Ko SJ. Corticotomy-assisted orthodontics. J Clin Orthod 2001;35:331-9.

19. Suya H. Corticotomy in orthodontics. In: Hosl E, Baldauf A editors. Mechanical and biological basics in orthodontic therapy. Heidelberg: Huthig Buch Verlag; 1991.

20. Kanno T, Mitsugi M, Furuki Y, Kozato S, Ayasaka N, Mori $\mathrm{H}$. Corticotomy and compression osteogenesis in the posterior maxilla for treating severe anterior open bite. Int $\mathrm{J}$ Oral Maxillofac Surg 2007;36:354-7.

21. Kim S, Park Y, Chung K. Severe anterior open bite malocclusion with multiple odontoma treated by $\mathrm{C}$-lingual retractor and horseshoe mechanics. Angle Orthod 2003;73:206-12.

22. Kim SH, Park YG, Chung K. Severe Class II anterior deep bite malocclusion treated with a $\mathrm{C}$-lingual retractor. Angle Orthod 2004;74:280-5.

23. Chung KR, Kim YS, Linton JL, Lee YJ. The miniplate with tube for skeletal anchorage. J Clin Orthod 2002;36:407-12.

24. Chung KR, Kim SH, Kook YA, Mo SS, Jung JA. Class II malocclusion treated by combining a lingual retractor and a palatal plate. Am J Orthod Dentofacial Orthop 2008;133: 112-23.

25. Kawakami T, Nishimoto M, Matsuda Y, Deguchi T, Eda S. Histologic suture changes following retraction of the maxillary anterior bone segment after corticotomy. Endod Dent Traumatol $1996 ; 12: 38-43$.

26. Ericsson I, Thilander B, Lindhe J, Okamoto H. The effect of orthodontic tilting movements on the periodontal tissues of infected and non-infected dentitions in dogs. J Clin Periodontol 1977;4:278-93. 
27. Ártun J, Urbye KS. The effect of orthodontic treatment on periodontal bone support in patients with advanced loss of marginal periodontium. Am J Orthod Dentofacial Orthop 1988;93: 143-8.

28. Yoshikawa Y. Effects of corticotomy on maxillary retraction induced by orthopedic force. J Matsumoto Dent Coll Soc 1987;13:292-320.
29. Fukunaga T, Kurodaa S, Kurosaka H, Takano-Yamamoto T. Skeletal anchorage for orthodontic correction of maxillary protrusion with adult periodontitis. Angle Orthod 2006;76:148-55.

30. Lee HK, Chung KR. The vertical location of the center of resistance for maxillary six anterior teeth during retraction using three dimensional finite element analysis. Korean J Orthod 2001;31:425-38 